\title{
DIFFICULTY ANALYSIS OF PHYSICS STUDENTS IN LEARNING ONLINE DURING PANDEMIC COVID-19
}

\author{
Naila Fauza ${ }^{* 1)}$, Ernidawati ${ }^{2)}$, Dina Syaflita ${ }^{3)}$ \\ ${ }^{1,2,3)}$ Physics Education, University of Riau \\ e-mail: ${ }^{*}$ nailafauza@lecturer.unri.ac.id \\ ernidawati@lecturer.unri.ac.id \\ dinasyaflita92@gmail.com
}

\begin{abstract}
COVID-19 attacked Wuhan city in December 2019 where the number of cases increased rapidly, but the clinical information of infected patients was limited. One of the negative effects related is the education sector. COVID-19 also changed the learning model drastically, all learning activities were carried out online. This causes students difficulties in learning. The purpose of the research was to analyze the difficulty factors of physics education students in distance learning during the COVID-19 pandemic. This type of research is descriptive research. Data collection techniques using a questionnaire. Research subjects were 80 students from Physics education at FKIP Riau University. The results of research online learning difficulties come from two factors, namely external and internal factors. External factors include non-current internet networks and very many student assignments. Internal factors related to students' learning difficulties, students generally have difficulty communicating and discussing both fellow students and with lecturers, misconceptions occur, difficulties in summarizing the material, and eye discomfort due to cellphone and laptop radiation.
\end{abstract}

Keywords: COVID-19, difficulty learning physics, online learning. 


\title{
ANALISIS KESULITAN BELAJAR FISIKA MAHASISWA DALAM JARINGAN SELAMA PANDEMI COVID-19
}

\author{
Naila Fauza ${ }^{* 1)}$, Ernidawati ${ }^{2)}$, Dina Syaflita ${ }^{3)}$ \\ ${ }^{1)}$ Pendidikan Fisika, Universitas Riau
}

\begin{abstract}
Abstrak
COVID-19 menyerang kota Wuhan pada bulan Desember 2019 dimana jumlah kasus meningkat dengan cepat, tetapi informasi klinis pasien yang terjangkit terbatas. Salah satu dampak negatif dari wabah corona berpengaruh pada sektor pendidikan. COVID-19 juga mengubah model pembelajaran secara drastis, seluruh kegiatan pembelajaran dilakukan secara daring (dalam jaringan). Hal tersebut menyebabkan mahasiswa kesulitan dalam belajar. Tujuan penelitian adalah mengetahui dan menganalisis faktor-faktor kesulitan mahasiswa pendidikan fisika dalam pembelajaran jarak jauh selama pandemi COVID-19. Jenis penelitian adalah penelitian deskriptif. Teknik pengumpulan data dengan menggunakan kuesioner. Subjek penelitian 80 mahasiswa dari prodi pendidikan Fisika di FKIP Universitas Riau. Hasil penelitian kesulitan belajar pembelajaran daring berasal dari dua faktor yaitu faktor eksternal dan internal. Faktor eksternal meliputi jaringan internet tidak lancar dan tugas mahasiswa sangat banyak. Faktor internal meliputi mahasiswa sulit fokus dalam belajar, umumnya mahasiswa sulit berkomunikasi dan berdiskusi baik sesama mahasiswa maupun bersama dosen, terjadi misskonsepsi, kesulitan merangkum materi, dan ketidak nyamanan mata karena radiasi handphone dan laptop.
\end{abstract}

Kata kunci: COVID-19, kesulitan belajar fisika, pembelajaran dalam jaringan.

\section{Pendahuluan}

COVID-19 (Coronavirus Disease-2019) merupakan wabah baru yang menimbulkan masalah global (Wang Chen et al. 2020). Wabah COVID-19 berawal dari sebuah daerah di China yaitu kota Wuhan. Pada bulan Desember 2019 COVID-19 menyerang kota Wuhan dimana jumlah kasus meningkat dengan cepat tetapi informasi klinis pasien yang terjangkit terbatas (Wang Dawei et al., 2020). Pada umumnya secara klinis didominasi oleh gejala pernafasan (Huang et al., 2020). Persentase tertinggi penyumbang angka kematian adalah lansia umur 75-84 tahun (Report, 2020).

Salah satu dampak negatif dari wabah corona berpengaruh pada sektor pendidikan (Nurkholis, 2020). Pemerintah Indonesia melalui kementrian pendidikan mengeluarkan surat edaran nomor 3 tahun 2020 tentang pencegahan covid-19 yaitu meliburkan secara nasional satuan pendidikan dan perguruan tinggi. COVID-19 juga mengubah model pembelajaran secara drastis, seluruh kegiatan pembelajaran dilakukan secara daring (dalam jaringan) mulai dari tingkat sekolah dasar sampai perguruan tinggi (Windhiyana, 2020).
Peran informasi (internet) sangat penting dalam proses pembelajaran (Hikam, 2020). Pemanfaatan teknologi informasi yang sangat pesat saat ini diantaranya e-learning, google classroom, whatsapp, zoom meeting serta media informasi lainya dapat menghubungkan dosen dan mahasiswa sehingga proses pembelajaran berjalan dengan baik (Pakpahan \& Fitriani, 2020). Teknologi komputer sebagai salah satu media dalam pembelajaran (Agustine, et al., 2014). Mahasiswa memanfatkan sumber internet untuk bahan belajar (Setiyani, 2010). Namun terdapat kekurangan pembelajaran jarak jauh. Kekurangan tersebut antara lain: hambatan untuk pembelajaran efektif seperti gangguan rumah tangga dan teknologi yang tidak dapat diandalkan, interaksi yang tidak memadai antara siswa dan pengajar, serta kebutuhan untuk pengalaman yang lebih banyak (Setiawan Rifqi, 2020). Hal tersebut menyebabkan mahasiswa kesulitan dalam belajar.

Faktor kesulitan belajar ditinjau dari eksternal dan internal. Faktor eksternal meliputi fasilitas dan sarana penunjang, kurikulum, waktu belajar, kegiatan siswa diluar jam belajar, lingkungan keluarga (keharmonisan keluarga, ekonomi keluarga, fasilitas belajar dirumah), hubungan dengan 
masyarakat, keterlibatan dengan kegiatan masyarakat, hubungan dengan teman pergaulan. Faktor internal meliputi faktor fisiologis (cacat tubuh dan kesehatan siswa), faktor psikologis (motivasi, minat), faktor peserta didik (gaya belajar dan kebiasaan belajar), faktor studi dan ekonomi. Selain itu, kekurangan pembelajaran jarak jauh yaitu kuota dan akses internet yang terbatas (Darmayanti, 2004), komunikasi yang terbatas sehingga tutor tidak mengetahui perkembangan dan kesulitan siswa (Indriani et al., 2018).

Berdasarkan hasil survey dan wawancara kepada beberapa mahasiswa, mereka mengeluh atas pembelajaran dalam jaringan. Maka dari itu perlu dilakukan penyelidikan analisis kesulitan belajar mahasiswa dalam jaringan selama pandemi COVID-19.

Tujuan penelitian adalah untuk mengetahui dan menganalisis faktor-faktor kesulitan mahasiswa dalam pembelajaran jarak jauh selama pandemi COVID-19, sehingga dapat diketahui dan dicari solusi kesulitan mahasiswa melakukan pembelajaran dalam jaringan selama pandemi COVID-19.

\section{Bahan dan Metode}

Penelitian dilakukan di Universitas Riau. Subjek penelitian 80 orang mahasiswa dari Program Studi Pendidikan Fisika di FKIP Universitas Riau. Jenis penelitian adalah penelitian deskriptif. Penelitian deskriptif mengambarkan analisa kesulitan belajar mahasiswa selama pembelajaran daring dengan tipe data kualitatif. Jenis penelitian termasuk penelitian kualitatif yang termasuk dalam kelompok penelitian deskriptif. Penelitian deskriptif tidak dimaksudkan untuk menguji hipotesis tertentu, tetapi hanya menggambarkan apa adanya tentang suatu variabel atau keadaan (Suharsimi, 2010). Salah satu kategori dari penelitian deskriptif adalah penelitian survei. Dalam penelitian ini diperlukan instrumen untuk menganalisis kesulitan belajar. Langkah-langkah penelitian deskriptif ini terdiri dari tiga tahap yaitu: tahap pertama, tahap deskripsi untuk mengumpulkan informasi, selanjutnya tahap reduksi untuk menentukan fokus masalah yang akan dideskripsikan. Terakhir tahap seleksi untuk menguraikan fokus menjadi komponen yang lebih rinci.

Teknik pengumpulan data dengan menggunakan kuesioner (angket). Kuesioner merupakan teknik pengumpulan data yang efesien, bila peneliti tahu dengan pasti variabel yang akan diukur dan tahu apa yang bisa diharapkan dari responden (Sugiyono, 2011). Instrumen dibangun dan dirancang melalui kajian literatur. Terdapat 16 item pertanyaan yang terdiri dari 7 item faktor internal dan 9 item faktor internal. Jawaban setiap item instrumen yang digunakan mempunyai pilihan jawaban positif dan negatif melalui dua pilihan jawaban ya atau tidak. Penyebaran angket melalui google form. Waktu pengisian angket dibatasi pada tanggal 13 Juni 2020 pukul 07.00 sampai 23.59 .

\section{Hasil dan Pembahasan}

Hasil penelitan analisis kesulitan belajar mahasiswa melalui pembelajaran dalam jaringan selama pandemi COVID-19 disebar menggunakan angket melalui google form. Terdapat 80 mahasiswa dalam pengisian angket. Hasil analisis dibagi menjadi dua yaitu faktor eksternal dan internal. Faktor ekternal kesulitan belajar terkait lingkungan dan kondisi luar. Sedangkan faktor internal merupakan kesulitan belajar berasal dari diri mahasiswa tersebut. Faktor eksternal meliputi ketersediaan fasilitas dan lingkungan yang mendukung. Faktor internal meliputi gaya belajar, kemampuan mahasiswa dan komunikasi.

Hasil dari angket faktor eksternal kesulitan belajar tersaji pada Gambar 1. Berdasarkan grafik Gambar 1, terdapat 6 indikator. Indikator 1 yaitu $88 \%$ mahasiswa mengaalami masalah jaringan, selebihnya $12 \%$ mahasiswa memiliki jaringan lancar. Hal ini disebabkan tempat tinggal (kampung halaman) mahasiswa tersebar di desa dan pelosok Riau bahkan luar Riau. Jangkauan internet memiliki keterbatasan, sehingga tidak sampai ke tempat tinggal mahasiswa tersebut. Hal ini sejalan dengan penelitian yang lain salah satu kesulitannya adalah akses internet yang tidak merata di setiap tempat (Ahmad Kholiqul Amin, 2017). 


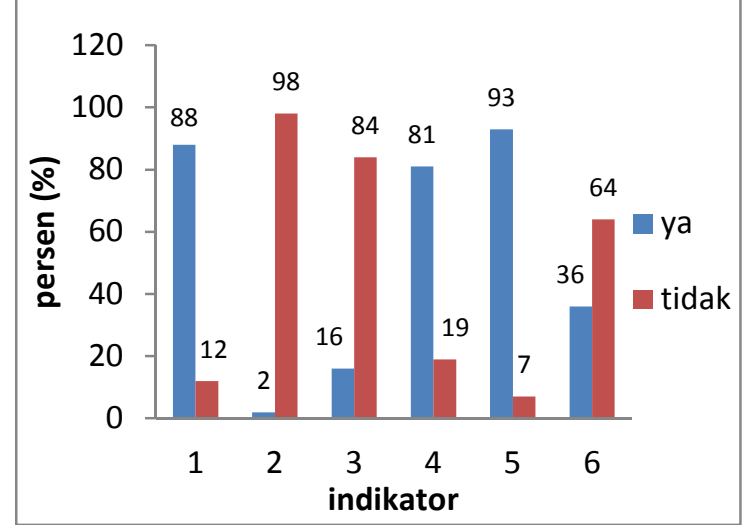

Gambar 1. Faktor eksternal kesulitan belajar.

Indikator 2, terdapat $98 \%$ mahasiswa telah memiliki alat komunikasi pembelajaran daring yaitu handphone android dan $2 \%$ (2 orang) tidak memiliki alat komunikasi. Sesuai dengan perkembangan zaman handphone andriod merupakan kebutuhan pokok dikalangan mahasiswa. Fitur handphone android yang beragam membantu mahasiswa dalam pembelajaran daring.

Indikator ke 3, sebanyak 16\% mahasiswa belum memiliki laptop dan komputer, selebihnya $84 \%$ mahasiswa sudah memiliki laptop. Laptop merupakan kebutuhan pokok mahasiswa untuk mengerjakan tugas perkuliahan. Harga laptop yang cukup tinggi, sehingga mahasiswa yang kemampuan ekonominya lemah belum mampu membeli laptop. Pemebelajaran online sulit diterapkan apabila sarana dan prasarana tidak mendukung seperti ketersediaan laptop (Ahmad Kholiqul Amin, 2017). Indikator ke 4, yaitu $81 \%$ mahasiswa tidak memiliki kuota internet yang memadai. Hal ini disebabkan kebutuhan kuota internet melonjak tinggi selama perkuliahan daring dibandingan sebelum pandemi COVID19 menyerang dunia. Indikator 5, sebanyak 93\% mahasiswa memiliki banyak tugas yang diberikan dosen. Tugas mandiri merupakan pengganti kegiatan perkulihan tatap muka. Selain itu dapat meningkatkan kemandirian mahasiswa. Tidak hanya membaca bahan perkulihan yang diberikan dosen, tetapi mencari bahan merupakan aktivitas mandiri. Indikator ke 6 , adalah 36\% mahasiswa mengalami kesulitan menggunakan aplikasi e-learning. Mahasiswa belum terbiasa dengan pembelajaran e-learning. Mahasiswa belajar autodidak untuk mempelajari e-learning.
Selain faktor eksternal, terdapat faktor internal yang mempengaruhi kesulitan belajar. Faktor internal disajikan dalam Gambar 2.

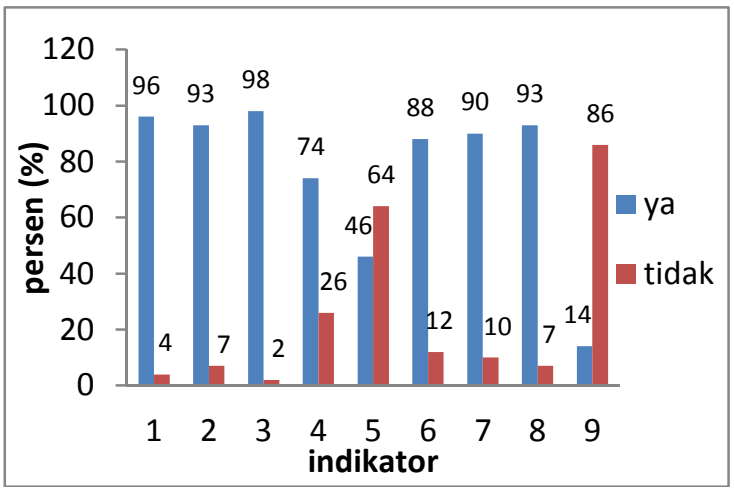

Gambar 2. Faktor internal kesulitan belajar.

Faktor internal terdiri dari 9 indikator. Indikator 1, yaitu 96\% mahasiswa tidak fokus mengikuti perkulihan daring. Hal ini disebabkan lingkungan yang tidak mendukung, contohnya gangguan TV, gadget, pekerjaan rumah, anggota keluarga, dan lain-lain. Indikator 2, yaitu 93\% mahasiswa mengalami kesulitan berdiskusi dengan dosen pengampu. Keterbatasan diskusi dalam pembelajaran daring bertatap muka tidak seperti pembelajaran langsung di kelas. Indikator ke 3, adalah 98\% mahasiswa kesulitan memahami materi perkuliahan. Kesulitan ini disebabkan komunikasi yang terbatas sehingga tutor (dosen) tidak mengetahui perkembangan dan kesulitan siswa et al. 2018). Hal ini disebabkan mahasiswa terbiasa menerima materi perkulihan langsung tatap muka. Melalui tatap muka di kelas mahasiswa bebas berdiskusi dan bereksplorasi materi perkuliahan.

Selanjutnya, Indikator ke 4, adalah $74 \%$ mahasiswa kesulitan merangkum materi perkuliahan. Materi disajikan secara daring dengan sumber belajar yang banyak, sehingga mahasiswa merasa sulit merangkum materi. Indikator ke 5, yaitu 46\% mahasiswa tidak tepat waktu dalam mengikuti perkulihan. Hal ini disebabkan mahasiswa lostcontrol waktu dengan kegiatan rumah yang banyak. Indikator ke 6, yakni $88 \%$ sesama mahasiswa kesulitan berdiskusi. Keberhasilan belajar daring tergantung pada tiga model komunikasi yaitu komunikasi mahasiswa dan dosen, mahasiswa dan sumber belajar dan antar sesama mahasiswa (Setiyani, 2010).

Indiktor ke 7 , yaitu 90\% mahasiswa mengalami misskonsepsi terutama mata kuliah 
keilmuan, karena penekanan konsep sulit dijelaskan melalui tulisan. Maka dari itu, mahasiswa perlu membaca banyak sumber belajar untuk memperjelas konsep dalam materi tersebut. Indikator ke 8, adalah 93\% terkait mata mahasiswa yang cepat lelah, karena radiasi cahaya yang dipancarkan layar laptop dan handphone menganggu mata. Terakhir, indikator ke 9, yaitu 14\% mahasiswa tidak mengikuti perkuliahan, artinya sebagian besar mahasiswa mengikuti perkulihan karena kontrol dosen terhadap absensi mahasiswa sangat penting. Akses mahasiswa hadir dalam perkuliahan fleksibel dimana saja.

\section{Kesimpulan dan Saran}

Berdasarkan paparan hasil dan pembahasan dapat disimpulkan bahwa kesulitan belajar mahsiswa pendidikan Fisika dalam pembelajaran daring selama pandemi COVID-19 berasal dari dua faktor yaitu faktor eksternal dan internal. Faktor eksternal meliputi jaringan internet tidak lancar dan tugas mahasiswa sangat banyak. Faktor internal meliputi mahasiswa sulit fokus dalam belajar, umumnya mahasiswa sulit berkomunikasi dan berdiskusi baik sesama mahasiswa maupun bersama dosen, terjadi miskonsepsi, kesulitan merangkum materi dan mata menjadi cepat lelah karena radiasi handphone dan laptop.

\section{Daftar Pustaka}

Agustine, Dwi, Ketang Wiyono, \& M. Muslim. (2014). Pengembangan elearning berbantuan virtual laboratory untuk mata kuliah praktikum fisika dasar II di Program Studi Pendidikan Fisika Fkip Unsri." Jurnal Inovasi dan Pembelajaran Fisika 1 (1): 33-43.

Ahmad Kholiqul Amin. (2017). Kajian konseptual model pembelajaran blended learning berbasis web untuk meningkatkan hasil belajar dan motivasi belajar. Jurnal Pendidikan Edutama, 4 (2).

Darmayanti, Tri. (2004). Pengembangan tutorial melalu media telepon pada pendidikan jarak jauh (Studi kasus di FISIP-Universitas Terbuka). Jurnal Pendidikan Terbuka dan Jarak Jauh, 5
(2), 108-27.

Hikam, Fajar Farham. (2020). E-Learning pada masa wabah Covid-19, 2, 194-203.

Huang, Chaolin, Yeming Wang, Xingwang Li, Lili Ren, Jianping Zhao, Yi Hu, Li Zhang, et al. (2020). Clinical features of patients infected with 2019 novel coronavirus in Wuhan, China. The Lancet, 395 (10223): 497-506. https://doi.org/10.1016/S01406736(20)30183-5.

Indriani, Tri Mughni, Toto Fathoni, \& Cepi Riyana. (2018). Implementasi blended learning dalam program pendidikan jarak jauh pada jenjang pendidikan menengah kejuruan. Edutcehnologia, 2(2), 129-39.

Nurkholis. (2020). Dampak pandemi novelcorona virus disiase (Covid-19) Terhadap psikologi dan pendidikan serta kebijakan pemerintah. Pgsd, 6(1), 39-49. https://ejournal.umc.ac.id/index.php/JPS.

Pakpahan, Roida, \& Yuni Fitriani. (2020). Analisa Pemanfaatan teknologi informasi dalam pembelajaran jarak jauh di tengah pandemi virus corona Covid-19, JISAMAR (Journal of Information System, Applied, Management, Accounting and Researh), 4(2), 30-36. p-ISSN : 25988700 Pri,

Report, Mortality Weekly. (2020). Severe outcomes among patients with corona virus disease 2019 (COVID-19) -United States, February 12-March 16, 2020. 2020;69:343-346. DOI: Http:// Dx.Doi.Org/10.15585/Mmwr.Mm6912e2. MMWR Morb Mortal Wkly Rep, 69 (12), 343-46. https://doi.org/10.15585/mmwr. mm6912e2.

Setiawan Rifqi, Adib. (2020). Lembar kegiatan literasi saintik untuk pembelajaran jarak jauh topik penyakit coronavirus 2019 (COVID-19). Jurnal Ilmu Pendidikan, 2 (1), 28-37. https://edukatif.org/index.php/ edukatif/index.

Setiyani, Rediana. (2010). Pemanfaatan internet sebagai sumber belajar. Dinamika Pendidikan, 5 (2), 117-33. https://doi.org/ 10.15294/dp.v5i2.4921.

Sugiyono. (2011). Metode penelitian pendidikan pendekatan kuantitatif, kualitatif dan $r \& d$. Bandung: Alfabeta.

Wang, Chen, Peter W., Horby, Frederic,k G,. Hayden, \& George, F. Gao. (2020). A novel coronavirus outbreak of global 
health concern. The Lancet, 395(10223), 470-73. https://doi.org/10.1016/S01406736(20)30185-9.

Wang, Dawei, Bo Hu, Chang Hu, Fangfang Zhu, Xing Liu, Jing Zhang, Binbin Wang, et al. (2020). Clinical characteristics of 138 hospitalized patients with 2019 Novel coronavirus-infected pneumonia in Wuhan, China. JAMA - Journal of the
American Medical Association, 323,(11), 1061-69. https://doi.org/10.1001/jama. 2020.1585.

Windhiyana, Ericha. (2020). Dampak Covid19 terhadap kegiatan pembelajaran online di perguruan tinggi kristen di Indonesia. Perspektif Ilmu Pendidikan, 34,(1), 1-8. https://doi.org/10.21009/pip.341.1. 